\title{
Comparative study of Cd uptake and tolerance of two Italian ryegrass (Lolium multiflorum) cultivars
}

\author{
Zhigang Fang ${ }^{1,2}$, Laiqing Lou ${ }^{1}$, Zhenglan Tai ${ }^{1}$, Yufeng Wang ${ }^{1}$, Lei Yang ${ }^{1}$ ， Zhubing Hu Corresp.. ${ }^{1}$, Qingsheng \\ Cai ${ }^{\text {Corresp. } 1}$ \\ ${ }^{1}$ College of Life Sciences, Nanjing Agricultural University, Nanjing, Jiangsu, China \\ 2 Kashghar University, Kashghar, Xinjiang, China \\ Corresponding Authors: Zhubing Hu, Qingsheng Cai \\ Email address: zhubinghu@njau.edu.cn, qscai@njau.edu.cn
}

Cadmium ( $\mathrm{Cd}$ ) is one of the most toxic heavy metals and is difficult to remove from contaminated soil and water. Italian ryegrass (Lolium multiflorum), as an energy crop, exhibits a valuable potential to develop $\mathrm{Cd}$ polluted sites due to its use as a biofuel rather than as food and forage. Previously, via a screening for Cd-tolerant ryegrass, the two most extreme cultivars (Idyll and Harukaze) with high and low Cd tolerance during seed germination, respectively, were selected. However, the underlying mechanism for $\mathrm{Cd}$ tolerance was not well investigated. In this study, we comparatively investigated the growth, physiological responses, and Cd uptake and translocation of Idyll and Harukaze when the seedlings were exposed to a $\mathrm{Cd}(0-100 \mu \mathrm{M})$ solution for 12 days. As expected, excess $\mathrm{Cd}$ inhibited seedling growth and was accompanied by an accumulation of malondialdehyde (MDA) and reduced photosynthetic pigments in both cultivars. The effects of $\mathrm{Cd}$ on the uptake and translocation of other nutrient elements ( $\mathrm{Zn}, \mathrm{Fe}, \mathrm{Mn}$ and $\mathrm{Mg}$ ) were dependent on $\mathrm{Cd}$ concentrations, cultivars, plant tissues and elements.

Compared with Harukaze, Idyll exhibited better performance with less MDA and higher pigment content. Furthermore, Idyll was less efficient in Cd uptake and translocation compared to Harukaze, which might be explained by the higher NPT (non-protein thiols) content in its roots. Taken together, our data indicate that Idyll is more tolerant than Harukaze, which partially resulted from the differences in Cd uptake and translocation. 
1 Comparative study of $\mathrm{Cd}$ uptake and tolerance of two Italian ryegrass

3 Zhigang Fang ${ }^{1,2}$, Laiqing Lou ${ }^{1}$, Zhenglan Tai ${ }^{1}$, Yufeng Wang ${ }^{1}$, Lei Yang ${ }^{1}$, Zhubing Hu${ }^{1}$,

4 Qingsheng Cai ${ }^{1}$

$5 \quad{ }^{1}$ College of Life Sciences, Nanjing Agricultural University, Nanjing, Jiangsu Province, People's Republic of China

$6 \quad{ }^{2}$ Kashghar University, Kashghar, Xinjiang, Province, People's Republic of China

7 Corresponding authors:

8 Qingsheng Cai, Zhubing $\mathrm{Hu}$

9 E-mail address: qscai@njau.edu.cn and zhubinghu@njau.edu.cn 
24 ABSTRACT

Cadmium (Cd) is one of the most toxic heavy metals and is difficult to remove from contaminated soil and water. Italian ryegrass (Lolium multiflorum), as an energy crop, exhibits a valuable potential to develop Cd polluted sites due to its use as a biofuel rather than as food and forage. Previously, via a screening for Cd-tolerant ryegrass, the two most extreme cultivars (IdyII and Harukaze) with high and low Cd tolerance during seed germination, respectively, were selected. However, the underlying mechanism for $\mathrm{Cd}$ tolerance was not well investigated. In this study, we comparatively investigated the growth, physiological responses, and Cd uptake and translocation of IdyII and Harukaze when the seedlings were exposed to a $\mathrm{Cd}(0-100 \mu \mathrm{M})$ solution for 12 days. As expected, excess Cd inhibited seedling growth and was accompanied by an accumulation of malondialdehyde (MDA) and reduced photosynthetic pigments in both cultivars. The effects of $\mathrm{Cd}$ on the uptake and translocation of other nutrient elements ( $\mathrm{Zn}, \mathrm{Fe}$, $\mathrm{Mn}$ and $\mathrm{Mg}$ ) were dependent on $\mathrm{Cd}$ concentrations, cultivars, plant tissues and elements. Compared with Harukaze, IdyII exhibited better performance with less MDA and higher pigment content. Furthermore, IdyII was less efficient in $\mathrm{Cd}$ uptake and translocation compared to Harukaze, which might be explained by the higher NPT (non-protein thiols) content in its roots. Taken together, our data indicate that IdyII is more tolerant than Harukaze, which partially resulted from the differences in Cd uptake and translocation.

Keywords Cadmium, Italian ryegrass, physiological response, tolerance, uptake and translocation

\section{INTRODUCTION}

Heavy metal contamination in agricultural soil and water introduced by human activities poses a serious environment issue (Bonfranceschi, Flocco \& Donati, 2009; Mwamba et al., 2016; Toth et al., 2016). Among heavy metals, cadmium (Cd), known as a highly toxic and nonbiodegradable pollutant, is easily taken up by plant roots and translocated to other parts (Nocito 
49

et al., 2011), thus threatening human health via food contamination and ecosystem safety (Agami $\&$ Mohamed 2013). In view of the difficulty of a clean up of Cd-contaminated soil by physical or chemical means, planting energy crops became a viable alternative for exploiting heavy-metal contaminated land (Shi \& Cai 2009; Zhang et al., 2013; Al Chami et al., 2015; Pandey, Bajpai \& Singh, 2016). Thus, increasing efforts have been devoted to isolating a tolerant cultivar and dissecting the mechanisms underlying their tolerance.

Several direct and indirect toxic effects caused by excess $\mathrm{Cd}$ have been well-documented. First, excess $\mathrm{Cd}$ generates free radicals and reactive oxygen species (ROS), which can oxidize proteins, DNA, lipids and carbohydrates, thus disturbing a number of physical and biological processes in plants (Belkhadi et al., 2010; Fernandez et al., 2013). For instance, excess Cd induced an accumulation of a lipid peroxidation product, MDA, in rice, which is an indicator of oxidative stress and disturbed cellular metabolism (Celekli, Kapi \& Bozkurt, 2013; Mostofa, Seraj \& Fujita, 2014; Xie et al., 2015). Second, the uptake of nutrient elements (Fe, $\mathrm{Mn}, \mathrm{Cu}$ and $\mathrm{Zn}$ ) is disturbed by Cd stress, which can impair the transport of these elements from the roots to aerial parts, thus leading to a reduction of electron transport in photosystem I transport due to the lack of chlorophyll synthesis (Aravind \& Prasad 2005; Lopes Júnior, Mazzafera \& Arruda 2014).

A set of strategies in plants have been found to cope with exogenous $\mathrm{Cd}$, which include active exclusion, vacuolar sequestration, retention in the roots, immobilization by cell walls and complexation by binding metal to low-molecular weight proteins (Ramos et al., 2002; Wahid, Arshad \& Farooq. 2010). It has been reported that reducing $\mathrm{Cd}$ accumulation by exclusion in the roots of Thlaspi arvense conferred enhanced tolerance in the Cd-tolerance ecotype (Martin et al., 2012). In Dittrichia viscosa (L.) Greuter, the responses of Cd toxicity involved Cd retention in the cell wall of the roots and the upregulated contents of non-protein thiols and organic acids (Fernandez et al., 2014). In wheat, Cd binds to the sulphur group of cysteine-forming Cd-PC complexes, reducing the free $\mathrm{Cd}^{2+}$ in the cytosol, and the Cd-phytochelatins (Cd-PCs) complexes are in turn transported into the vacuole or out of the cell by ATP binding cassette transporters (Greger et al., 2016). 
Different approaches have been employed to unravel the mechanisms that address Cd toxicity, such as screening for cadmium sensitive mutants (McHugh \& Spanier 1994) and dissecting the role of metal transporters by transgenic manipulations (Uraguchi \& Fujiwara 2012). The cultivar screen is another way to find evolved mechanisms in plants due to different environments and natural variations. This has been conducted for $\mathrm{Cd}$ tolerance and accumulation in several species such as hemp (Shi et al., 2012), Indian mustard (Gill, Khan \& Tuteja, 2011), barley (Sghayar et al., 2014) and castor (Zhang et al., 2014), revealing that Cd tolerance is related to the characteristics of plant morphology, the amounts of phytochrome synthesis, Cd uptake and thiol levels.

Italian ryegrass (Lolium multiflorum), also called annual ryegrass, is broadly grown in the south of China during the winter before the emergence of rice to relieve green fodder shortages (Ye et al., 2015). Recently, this species has been considered an appropriate material for bioethanol production due to its high ethanol conversion, rapid growth and low input costs (Yasuda et al., 2015; Ye et al., 2015). Two recent studies reported that Italian ryegrass had a high tolerance to $\mathrm{Cd}$ during seed germination and was able to be cultivated in sites polluted by mine tailings (Liu et al., 2013; Mugica-Alvarez et al., 2015). In regards to these properties, Italian ryegrass has been suggested as a new species for the bioremediation of heavy metal polluted soils (including Cd) (Yamada et al., 2013). However, compared with other species, little information is available concerning the capacity of $\mathrm{Cd}$ tolerance and uptake and tolerance mechanisms in Italian ryegrass. Here, through investigating the underlying causes for differential Cd tolerance in two ryegrass cultivars (IdyII and Harukaze), we found that IdyII is less efficient in Cd uptake and translocation than Harukaze. Furthermore, a high NPT content in IdyII might be one of causes for low $\mathrm{Cd}$ translocation. Our findings can provide a new tool for further dissecting the molecular mechanisms of $\mathrm{Cd}$ uptake and translocation in ryegrass cultivars and will be helpful for breeding Italian ryegrass as a bioenergy crop for heavy metal remediation.

\section{MATERIALS AND METHODS}

\section{Plant cultivation}


103 Two extreme ryegrass cultivars (IdyII and Harukaze) with high and low Cd tolerance during seed

104

105

106

107

108

109

110

111

112

113

114

115

116

117

118

119

120

121

122

123

124

125

126

127

128

129 germination (Fang et al., 2016), respectively, were selected for this study. Seeds were sterilized with $10 \% \mathrm{H}_{2} \mathrm{O}_{2}$ for $10 \mathrm{~min}$, rinsed thoroughly with distilled water, and germinated via immersion in distilled water at $25^{\circ} \mathrm{C}$ in the dark. After five days, uniform seedlings were transferred to 1-L plastic pots (14 plants per pot) filled with 1/4 Hoagland's solution. Seedlings were maintained for 10 days in a growth chamber at a $12 \mathrm{~h} \mathrm{light/dark} \mathrm{cycle} \mathrm{with} 300 \mu \mathrm{mol} \mathrm{m}^{-2} \mathrm{~s}^{-1}$ light intensity, a day/night temperature of $25 / 20{ }^{\circ} \mathrm{C}$ and $65 \pm 5 \%$ relative humidity. Five $\mathrm{Cd}$ concentrations for the treatments were as follows: $0,5 \mu \mathrm{M}, 10 \mu \mathrm{M}, 25 \mu \mathrm{M}, 50 \mu \mathrm{M}$, and $100 \mu \mathrm{M}$ $\mathrm{Cd}$ as $\mathrm{CdCl}_{2} \cdot 2.5 \mathrm{H}_{2} \mathrm{O}$ (analytical reagent) was added to the nutrient solution. Each treatment had six replicates. The nutrient solution was renewed every 3 days, and the $\mathrm{pH}$ was adjusted to 6.5 with $2 \mathrm{M} \mathrm{NaOH}$ or $2.7 \mathrm{M} \mathrm{HCl}$.

After a 12-day $\mathrm{Cd}$ exposure, plants were divided into two groups and collected. One group was for biomass and $\mathrm{Cd}$ concentration determination, and the other group was for physiological index measurements, including chlorophyll content, lipid peroxidation and non-protein thiols (NPT). Each group had three replicates.

\section{Estimation of plant growth and $\mathrm{Cd}$ accumulation}

The harvested plants were soaked in $20 \mathrm{mM} \mathrm{Na}_{2}$-EDTA for $15 \mathrm{~min}$, rinsed with distilled water to remove metals on the root surfaces, and separated into roots and shoots. Subsequently, samples were oven-dried at $70{ }^{\circ} \mathrm{C}$ overnight. The dried samples were weighed and digested with mixed acid $\left[\mathrm{HNO}_{3}+\mathrm{HClO}_{4}(85: 15, \mathrm{v} / \mathrm{v})\right]$. The concentrations of $\mathrm{Cd}$, zinc $(\mathrm{Zn})$, iron $(\mathrm{Fe})$, manganese $(\mathrm{Mn})$ and magnesium $(\mathrm{Mg})$ were determined by an inductively coupled plasma optical emission spectrometer (ICP-OES, Optima 2100 DV, PerkinElmer, Inc. US).

The TIs (tolerance index), translocation factors (TFs), bioconcentration factors (BCF), and Cd accumulation were determined according to the method of Chen et al. (2011):

$$
\begin{aligned}
& \text { TIs }=\text { biomass }_{\mathrm{Cd}} / \text { biomass } \\
& \mathrm{TFs}=\mathrm{Cd}_{\text {concentration in shoot }} / \mathrm{Cd}_{\text {concentration in root }} \\
& \mathrm{BCF}=\mathrm{Cd} \text { concentration in root } / \mathrm{Cd}_{\text {concentration in the nutrient solution }}
\end{aligned}
$$


130

131

132

133

134

135

136

137

138

139

140

141

142

143

144

145

146

147

148

149

150

151

152

153

154

155

156

Cd accumulation $=[\text { biomass }]_{\text {dry weight }} \times[\mathrm{Cd}]_{\text {concentration in plant tissues }}$

Total $\mathrm{Cd}$ accumulation $=\mathrm{Cd}$ accumulation in root $+\mathrm{Cd}$ accumulation in shoot

Cadmium distribution proportion of root $=\mathrm{Cd}$ accumulation in root/ Total $\mathrm{Cd}$ accumulation

\section{Estimation of photosynthetic pigment contents}

$100 \mathrm{mg}$ of the middle portion of fresh leaf slices were taken for pigments extraction with $10 \mathrm{~mL}$ $95 \%$ ethanol for $24 \mathrm{~h}$ in the dark. The absorbances of pigment extract were measured at wavelengths of 665, 649 and $470 \mathrm{~nm}$ with spectrophotometry (SHIMADZU UV-2450, Kyoto, Japan). Chlorophyll a (Chl a), Chlorophyll b (Chl b) and carotenoids (Car) were estimated using the following equations (Knudson et al.,1977), respectively:

Chl a $=13.95 \times \mathrm{A}_{665}-6.88 \times \mathrm{A}_{649}$

Chl $b=24.96 \times \mathrm{A}_{649}-7.32 \times \mathrm{A}_{665}$

$\mathrm{Car}=\left(1000 \times \mathrm{A}_{470}-2.05 \times \mathrm{Chl} \mathrm{a}-114.8 \times \mathrm{Chl} \mathrm{b}\right) / 245$

\section{Estimation of lipid peroxidation}

The level of lipid peroxidation in root and leaf was estimated with 2-thiobarbituric acid (TBA) reactive metabolites chiefly malondialdehyde (MDA) as described by Ali et al. (2014). Briefly, plant fresh tissues $(0.1-0.3 \mathrm{~g})$ were homogenized in $5 \mathrm{~mL}$ of $0.25 \%$ TBA made in $10 \%$ trichloroacetic acid. The extracts were heated at $95{ }^{\circ} \mathrm{C}$ for $30 \mathrm{~min}$ and then quickly cooled on ice. After centrifugation at $10000 \mathrm{~g}$ for $10 \mathrm{~min}$, the absorbance of the supernatant was measured at 532 and $600 \mathrm{~nm}$. MDA contents was calculated with the following formula: $\mathrm{MDA}=6.45 \times\left(\mathrm{A}_{532^{-}}\right.$ $\left.\mathrm{A}_{600}\right)$.

\section{Determination of non-protein thiols}

Non-protein thiols (NPT) were assayed following Tian et al. (2011) with minor modifications. Fresh tissues (approximately $0.3 \mathrm{~g}$ ) were homogenized in $3 \mathrm{~mL}$ ice-cold $5 \%$ sulfosalicylic acid solution and centrifuged at $12000 \times \mathrm{g}\left(4^{\circ} \mathrm{C}\right)$ for $15 \mathrm{~min}$. The resulting supernatant was used for NPT assays. First, $0.3 \mathrm{~mL}$ of the supernatant was mixed with $1.2 \mathrm{~mL} 0.1 \mathrm{M}$ K-phosphate buffer (pH 7.6) and $50 \mu \mathrm{L} 6$ mM 5,5'-dithiobis-2- nitrobenzoic acid (DTNB) (dissolved in 5 mM EDTA and $0.1 \mathrm{M}$ phosphate buffer solution at $\mathrm{pH}$ 7.6). The mixture was incubated at room temperature 
157

158

159

160

161

162

163

164

165

166

167

168

169

170

171

172

173

174

175

176

177

178

179

180

181

182

183

for $20 \mathrm{~min}$ and then measured for absorbance at $412 \mathrm{~nm}$ with spectrophotometry. The NPT content was estimated with a standard curve of reduced glutathione in the range of 0-100 $\mu \mathrm{g} \mathrm{mL}^{-}$ 1.

\section{Statistical analysis}

Statistical analyses were performed using a two-way analysis of variance (ANOVA) with SPSS Version 20.0 (SPSS Inc., USA). Duncan's multiple range test was employed to compare the changes among the different treatments at $P<0.05$. The correlations among TIs, Cd uptake, Cd TFs, Cd accumulation, MDA content and NPT content of the two cultivars in the roots in plant roots were determined by Pearson's correlation analysis.

\section{RESULTS}

\section{Plant biomass, TIs and root/shoot ratio response to $\mathrm{Cd}$ stress}

Increasing the $\mathrm{Cd}$ supply in the medium posed variable effects on plant biomass, TIs and the root/shoot ratio (Table 1). Cd treatments tended to reduce the biomass of both cultivars. The biomass of IdyII was significantly higher than that of Harukaze in the same treatment $(P<0.01)$, however biomass reductions with increasing $\mathrm{Cd}$ dose from $5 \mu \mathrm{M}$ to $100 \mu \mathrm{M}$ were not significant between IdyII and Harukaze. Similar alterations were also observed with the TIs. For example, when exposed to $25 \mu \mathrm{M} \mathrm{Cd}$, root biomass was reduced by $37 \%$ in Harukaze and $22 \%$ in IdyII. A clear decline in the roots/shoot ratio was demonstrated in both cultivars with increasing $\mathrm{Cd}$ concentrations.

\section{Ecotoxicological response based on the plant biomass inhibition rate}

As shown in Table 2, positive correlations were observed between the inhibition of plant biomass (root and shoot) and $\mathrm{Cd}$ concentrations in the solution $(P<0.01)$, which was represented by the quadratic equation. To evaluate toxicity, the inhibitory concentration (IC50; Cd concentration when the root or shoot biomass decreased by $50 \%$ compared with the control) and lethal concentration (IC90; Cd concentration when the root or shoot biomass decreased by $90 \%$ compared with the control) were determined by the fitting equation. The IC50 values of the shoots and roots of IdyII were 1.9-fold and 3.2-fold higher than that of Harukaze, respectively. 
184 The lethal concentration of the roots and shoots (IC90) in IdyII were also higher than that of

185 Harukaze, implying that IdyII was more tolerant to Cd compared to Harukaze.

186 Cd concentration, accumulation in plant tissues, and BCFs and TFs responses to Cd stress

187 With elevating $\mathrm{Cd}$ concentrations in the treatment solutions, root $\mathrm{Cd}$ concentration in both 188 cultivars increased, ranging from 2.09 to $9.89 \mathrm{mg} \cdot \mathrm{g}^{-1}$ in Harukaze and from 1.26 to $6.89 \mathrm{mg} \cdot \mathrm{g}^{-1}$ 189 in IdyII. Cd concentrations in Harukaze roots were higher than that of IdyII roots, especially at the 50 to $100 \mu \mathrm{M} \mathrm{Cd}$ treatments (Fig. $1 \mathrm{~A}, P<0.01$ ). Similar trends were also observed in the shoots (Fig. 1B). A gradual increase of Cd TFs in Harukaze was correlated with the increasing $\mathrm{Cd}$ concentration in the treatment solutions, whereas no significant $\mathrm{Cd}$ TFs changes in IdyII were observed. The Cd TF value in Harukaze was significantly higher than that in IdyII after exposure to the highest $\mathrm{Cd}$ concentration (Fig. $1 \mathrm{C}, P<0.01$ ). $\mathrm{Cd}$ accumulation in the roots of Harukaze remained constant, while there was a dramatic increase in IdyII with the application of 25-100 $\mu \mathrm{M} \mathrm{Cd}$ in the treatment solutions (Fig. 1D). An increasing trend of $\mathrm{Cd}$ accumulation in the shoots and total accumulation was observed with an increasing $\mathrm{Cd}$ supply, and their accumulation amounts in IdyII were significantly higher than that in Harukaze in the presence of higher Cd dosages (Figs. 1E and 1F, $P<0.05$ ).

The proportion of cadmium distribution in the roots was 78.5 - $45.4 \%$ in Harukaze and 67.2 $54.7 \%$ in IdyII under Cd stress. The distribution proportion in both Harukaze and IdyII significantly decreased with the $25 \mu \mathrm{M}$ and $100 \mu \mathrm{M}$ Cd treatments, respectively (Fig. 2A, $P<$ 0.01). The increasing Cd supply reduced the root BCFs of the two cultivars (Fig. 2B), and the reduction was especially obvious in Harukaze (range from 3715 to 880). At low Cd treatments $(5-10 \mu \mathrm{M})$, the BCFs of Harukaze were markedly higher than that of IdyII $(P<0.01)$.

\section{Effects of Cd on plant mineral concentrations and TFs}

Cadmium treatments altered the uptake and TFs of several nutrient elements (Fig. 3). Compared with the control, the 25 - $100 \mu \mathrm{M}$ Cd supply markedly increased the $\mathrm{Zn}$ and Fe concentrations in the roots of Harukaze (Figs. 3A and 3B), whereas the Mn concentration in the roots of Harukaze was significantly decreased with lower Cd concentrations (5 and $10 \mu \mathrm{M})$ (Fig. 3C). Additionally, 
$211 \mathrm{Mg}$ concentration was greatly increased at the highest Cd concentrations (Fig. 3D). In contrast,

212 compared with the control, $100 \mu \mathrm{M} \mathrm{Cd}$ significantly promoted $\mathrm{Zn}$ uptake in the roots of IdyII

213 (Fig. 3A), while the uptakes of Fe, Mn, and Mg exhibited no change in the roots of IdyII (Figs.

$2143 \mathrm{~B}, 3 \mathrm{C}$ and 3D). In the shoot, Cd supply did not affect $\mathrm{Zn}$ and $\mathrm{Mg}$ concentrations in both

215 cultivars, but severely decreased Mn concentrations (Figs. 3E, 3H and 3G). Compared with the

216 control, shoot $\mathrm{Fe}$ concentrations in IdyII exhibited a gentle decrease with increasing $\mathrm{Cd}$

217 concentration, while no significant change occurred in Harukaze (Fig. 3F). In both cultivars, Zn

218 TFs were significantly inhibited at the $25-100 \mu \mathrm{M} \mathrm{Cd}$ treatments (Fig. 3I), and the amounts in

219 IdyII were significantly higher than that of Harukaze. Fe TFs reached a maximum in both

220 cultivars under $5 \mu \mathrm{M} \mathrm{Cd}$ and then showed a decrease with increasing Cd (Fig. 3J). Cd treatments

221 in IdyII significantly reduced Mn TFs and had no change in Mg TFs. In contrast, the TFs of Mn

222 and $\mathrm{Mg}$ in Harukaze decreased considerably only at the highest concentration of Cd (Figs. 3K

223 and 3L). According to a two-way ANOVA analysis, significant differences in the concentrations

224 of Fe and $\mathrm{Mn}(P<0.01)$ of the roots were found between the two cultivars, while no significant

225 interaction were observed for other parameters (Figs. 3A to 3L), indicating these two cultivars

226 only respond significantly different for the uptakes of Fe and Mn when exposed in excess Cd.

227 Effects of $\mathrm{Cd}$ on pigment content, lipid peroxidation and NPT content

228 The cadmium supply tended to reduce chlorophyll a, chlorophyll b, chlorophyll $(\mathrm{a}+\mathrm{b})$ and Car

229 contents in both cultivars (Table 3). For example, the chlorophyll a, chlorophyll b, and Car 230 content decreased by $42.5 \%, 44.7 \%$ and $44.4 \%$ in Harukaze and by $11.8 \%, 5.9 \%$, and $22.2 \%$

231 in IdyII under $25 \mu \mathrm{M}$ Cd stress, respectively. The chlorophyll a, chlorophyll b and chlorophyll

$232(\mathrm{a}+\mathrm{b})$ content of IdyII was significantly higher than that of Harukaze at 25-100 $\mu \mathrm{M} \mathrm{Cd}$

233 concentrations $(P<0.01)$; a similar trend occurred in Car under 50-100 $\mu \mathrm{M} \mathrm{Cd}$ stress. The Cd

234 treatments did not affect the $\mathrm{Chl} \mathrm{a} / \mathrm{b}$ ratio of IdyII but significantly reduced the $\mathrm{Chl} \mathrm{a} / \mathrm{b}$ ratio of

235 Harukaze at $100 \mu \mathrm{M} \mathrm{Cd}$.

236 The MDA content in plant tissues was increased with elevated $\mathrm{Cd}$ concentrations, and the 237 amounts in the leaves were higher than in the roots (Fig. 4A $P<0.01$ ). Compared with the 
238

239

240

241

242

243

244

245

246

247

248

249

250

251

252

253

254

255

256

257

258

259

260

261

262

263

control, when treated with high $\mathrm{Cd}$ concentrations (50 and $100 \mu \mathrm{M})$, the MDA content of the seedling roots increased by $252.5 \%$ and $610.2 \%$ in Harukaze but only by $140.7 \%$ and $291.7 \%$ in IdyII, respectively. Similarly, the MDA content of the leaves in Harukaze increased sharply with the $25-100 \mu \mathrm{M} \mathrm{Cd}$ treatments and was considerably higher than that of IdyII (Fig. 4B, $P<$ $0.01)$.

As shown in Fig. 5, compared with the control, the NPT content in the roots of IdyII increased at least 3 times with the application of $5 \mu \mathrm{M} \mathrm{Cd}$ and reached its maximum under $50 \mu \mathrm{M} \mathrm{Cd}$. No significant change occurred in Harukaze with the addition of $5-50 \mu \mathrm{M} \mathrm{Cd}$ in the medium (Fig. 5A). Furthermore, the NPT content in the roots of IdyII were significantly higher than that of Harukaze with the treatments of $10-100 \mu \mathrm{M} \mathrm{Cd}(P<0.01)$. The NPT content in the shoots of the two cultivars were also enhanced under Cd stress. The values in IdyII were significantly higher than that in Harukaze at the $25-100 \mu \mathrm{M}$ Cd treatments (Fig. 5B, $P<0.05$ ). By a two-way ANOVA analysis, a significant interaction was found (Figs 5A and 5B), demonstrating that both cultivars responded significantly different to Cd treatments for NTP production in root and shoot.

\section{Correlation analysis}

Pearson's correlation analysis was carried out to investigate the correlations among TIs, Cd uptake, Cd TFs, Cd accumulation, MDA content and NPT content of the two cultivars in the roots (Table 4). TIs were negatively correlated to Cd concentration, MDA content and Cd TFs. Cd uptake and TFs were positively correlated to MDA content. Additionally, a positive correlation was observed between Cd accumulation and NPT content.

\section{DISCUSSION}

In this study, our data demonstrated that Italian ryegrass possesses a stronger capacity in $\mathrm{Cd}$ uptake than common crops. After 12 days of exposure at $50 \mu \mathrm{M} \mathrm{Cd}$, the $\mathrm{Cd}$ concentration in Italian ryegrass reached at least $4.9 \mathrm{mg} \cdot \mathrm{g}^{-1}(\mathrm{DW})$ in the roots and $0.4 \mathrm{mg} \cdot \mathrm{g}^{-1}$ (DW) in the shoots (Fig. 1A and B). These concentrations are higher than that in rice after 15 days of exposure at 50 $\mu \mathrm{M} \mathrm{Cd}$ (Lin et al., 2012), which is $0.35 \mathrm{mg} \cdot \mathrm{g}^{-1}$ (DW) in the roots and $0.15 \mathrm{mg} \cdot \mathrm{g}^{-1}$ (DW) in the 
264

265

266

267

268

269

270

271

272

273

274

275

276

277

278

279

280

281

282

283

284

285

286

287

288

289

290

shoots, as well as that in maize after 15 days of exposure at $100 \mu \mathrm{M} \mathrm{Cd}$ (Wang et al., 2007), which is $1.95 \mathrm{mg} \cdot \mathrm{g}^{-1}(\mathrm{DW})$ in the roots and $0.35 \mathrm{mg} \cdot \mathrm{g}^{-1}(\mathrm{DW})$ in the shoots.

The biomass reduction in the roots was more visible than that in the shoots when Cd levels were over $10 \mu \mathrm{M}$ (Table 1). Similar results were reported in barley (Tiryakioglu et al., 2006), and the reason may be the fact that the roots are directly exposed to $\mathrm{Cd}$ (Hegedüs, Erdei \& Horváth 2001). As plant biomass and TIs are two important parameters to evaluate the Cd tolerance in plants (Metwally et al., 2005; Shi et al., 2012), the biomass of the roots and shoot in Harukaze and TIs were reduced over $50 \%$ under 50 and $100 \mu \mathrm{M} \mathrm{Cd}$, which was not observed in IdyII (Table 1), thus demonstrating that IdyII was more tolerant to Cd than Harukaze. This was further supported by the higher IC50 and IC90 of Cd toxicity in IdyII (Table 2), which are two parameters commonly representing phytotoxin under a threshold and acute toxicity, respectively (Paschke, Valdecantos \& Redente, 2005; An, 2006; Pannacci, Pettorossi \& Tei 2013).

Although $\mathrm{Cd}$ is a non-redox metal unable to produce reactive oxygen species (ROS) through single election transfer, $\mathrm{Cd}$ could interfere with the antioxidant defence system by replacement of metal cofactors enzymes, leading to the diminishment of the capacity for ROS removal (Wahid, Arshad \& Farooq. 2010). Cd also affects the functions of two important organelles, the mitochondria and chloroplasts, which in turn disturb their election transfers and generate free radicals and ROS in the cell (Celekli, Kapi \& Bozkurt, 2013; Mostofa, Seraj \& Fujita, 2014). The accumulated ROS can interact with proteins, lipids, carbohydrates, and DNA, perturbing a number of physiological processes (Gallego et al., 2012). In IdyII and Harukaze, the Cd supply enhanced the MDA content, indicating Cd induced the oxidation of lipids (Fig. 4). The lipid peroxidation might partially be attributed to the reduction in photosynthetic pigments under $\mathrm{Cd}$ stress in both cultivars (Table 3). Relatively high MDA content and low photosynthetic pigments demonstrated that Cd-induced toxicity in Harukaze was more severe than in IdyII, which was consistent with their $\mathrm{Cd}$ tolerance. Similar correlations between $\mathrm{Cd}$ tolerance and MDA content were observed in oilseed cultivars (Wu et al. 2015), the leaves of Indian mustard cultivars (Gill, Khan \& Tuteja, 2011) and Artichoke cultivars (Chen et al., 2011). 
Apart from oxidative damage, the uptake, transport, and subsequent distribution of nutrient elements in IdyII and Harukaze were affected by the presence of Cd (Fig. 3). An elevated Cd dosage increased $\mathrm{Zn}, \mathrm{Fe}, \mathrm{Mg}$ and $\mathrm{Mn}$ concentrations in Harukaze roots, whereas it did not significantly increase that in the IdyII roots, except for Zn (Fig. 3A-D). Possibly, the metal transportation systems in the roots are different between Harukaze and IdyII, and Harukaze may have a high-dose $\mathrm{Cd}$ activated transportation system. This is further supported by the higher $\mathrm{Cd}$ concentrations in Harukaze. Likewise, $\mathrm{Cd}$ promoting the uptake of $\mathrm{Mg}, \mathrm{Ca}$, and $\mathrm{Fe}$ were reported in tomato (Kisa, Ozturk \& Tekin 2016). No significant differences in metal concentration were observed between the shoots of Harukaze and IdyII, indicating that cultivar differences in metal uptake are mainly in the roots rather than in the shoots. Goncalves et al. (2009) also suggested that microelement uptake, such as $\mathrm{Fe}^{2+}, \mathrm{Mn}^{2+}$ and $\mathrm{Zn}^{2+}$, was determined by the level of $\mathrm{Cd}$ in the substrate, cultivar and plant tissue specificity in potato (Solanum tuberosum). Several metal transporters have been identified that translocate nutrient elements from the roots to the shoot, such as NRAMP families and ZIP families (Choppala et al., 2014). With exposure to Cd, the Cd TF remained constant in IdyII and increased in Harukaze along with increasing concentration (Fig. 1C), whereas the TFs of Zn, Fe and Mn exhibited a decline (Fig. 3I, 3J and 3K), indicating that there may be possible competition with the metal transporters for translocation between $\mathrm{Cd}$ and other micronutrients in Italian ryegrass. It was reported that there were antagonistic effects from $\mathrm{Cd}$ and microelement elements $(\mathrm{Zn}, \mathrm{Fe}, \mathrm{Mn})$ using the same transporters and/or cation channels as Ca and Mg (Sarwar et al., 2010; Kisa, Ozturk \& Tekin 2016).

Non-protein thiols (NPT), including glutathione, thiol-rich peptides and other SH groups, play an important role in defence response against the detoxification of heavy metals in plants (Ozdener \& Aydin 2009; Nadgorska-Socha et al., 2013). In our study, Cd concentration in the roots and shoots of Harukaze were significantly higher than that of IdyII, whereas the NPT content was lower in Harukaze than in IdyII (Figs. 1A, 1B and Fig. 5). NPT are essential for the synthesis of Cd-binding peptides such as phytochelatins, which inactivate and sequester $\mathrm{Cd}$ by forming stable Cd-complexes in the vacuole (Cobbett 2000). The high NPT in IdyII may promote Cd 
318

319

320

321

322

323

324

325

326

327

328

329

330

331

332

333

334

335

336

337

338

339

340

341

342

343

344

sequestration into the vacuole and block its translocation, thus leading to the decline of the $\mathrm{Cd}$ TF. A similar phenomenon was observed in the variation of $\mathrm{Cd}$ tolerance among cultivars of cabbage and barley, suggesting that NPT content may be an important indicator for Cd tolerance (Tiryakioglu et al., 2006; Sun et al., 2013). Except for Cd, the higher NPT content in IdyII might be also contributed to the decreased translocation of $\mathrm{Zn}$ from the roots to the shoots (Fig. 3I). Furthermore, in comparison with Harukaze, a lower Cd concentration in the root of Idyll indicates that Idyll also is an excluder that does not take up and transport Cd easily, the underlying mechanism of which will need to be further investigated.

\section{CONCLUSIONS}

In the present study, the biomass, Cd uptake, translocation, accumulation, and physiology parameters of two Italian ryegrass cultivars were significantly affected by Cd treatments. Compared with Harukaze, IdyII is a Cd-tolerant cultivar, exhibiting a low Cd uptake and a high NPT content. These two distinct capacities may be the major physiological changes that contributed to the difference of $\mathrm{Cd}$ tolerance between the two cultivars. Taken together, our data demonstrates that IdyII is more tolerant than Harukaze, which is correlated with low Cd uptake and high NPT content. This will be helpful in investigating the molecular mechanisms of Cd uptake and translocation in Italian ryegrass.

\section{ACKNOWLEDGEMENTS}

We would like to thank Chunhua Zhang, who is working at the Experimental Center of Life Science, Nanjing agricultural university, for samples determination during phases of the project. We thank the seeds provided by Chenglong Ding, manager of Livestock Science, Jiangsu Academy of Agricultural Sciences. We also thank Dr. Gaoling Shi for his help with discussion and comments on the early version of this manuscript.

\section{REFERENCES}

Agami RA, Mohamed GF. 2013. Exogenous treatment with indole-3-acetic acid and salicylic acid alleviates cadmium toxicity in wheat seedlings. Ecotoxicology and Environmental Safety 94:164-171 DOI 10.1016/j.ecoenv.2013.04.013. 
345

346

347

348

349

350

351

352

353

354

355

356

357

358

359

360

361

362

Al Chami Z, Amer N, Al Bitar L, Cavoski I. 2015. Potential use of Sorghum bicolour and Carthamus tinctorius in phytoremediation of nickel, lead and zinc. International Journal of Environmental Science and Technology 12:3957-3970 DOI 10.1007/s13762-015-0823-0.

Ali B, Gill RA, Yang S, Gill MB, Ali S, Rafiq MT, Zhou W. 2014. Hydrogen sulfide alleviates cadmium-induced morpho-physiological and ultrastructural changes in Brassica napus. Ecotoxicology and Environmental Safety 110:197-207 DOI 10.1016/j.ecoenv.2014.08.027.

An YJ. 2006. Assessment of comparative toxicities of lead and copper using plant assay. Chemosphere 62:1359-1365 DOI 10.1016/j.Chemosphere.2005.07.044.

Aravind P, Prasad MNV. 2005. Cadmium-Zinc interactions in a hydroponic system using Ceratophyllum demersum L: adaptive ecophysiology, biochemistry and molecular toxicology. Brazilian Journal of Plant Physiology 17:3-20 DOI 10.1590/S167704202005000100002.

Belkhadi A, Hediji H, Abbes Z, Nouairi I, Barhoumi Z, Zarrouk M, Chaibi W, Djebali W. 2010. Effects of exogenous salicylic acid pre-treatment on cadmium toxicity and leaf lipid content in Linum usitatissimum L. Ecotoxicology and Environmental Safety 73:1004-1011 DOI 10.1016/j.ecoenv.2010.03.009.

Bonfranceschi BA, Flocco CG, Donati ER. 2009. Study of the heavy metal phytoextraction capacity of two forage species growing in an hydroponic environment. Journal of Hazardous Materials 165:366-371 DOI 10.1016/j.jhazmat.2008.10.024.

Celekli A, Kapi M, Bozkurt H. 2013. Effect of cadmium on biomass, pigmentation, malondialdehyde, and proline of Scenedesmus quadricauda var. longispina. Bulletin of Environmental Contamination and Toxicology 91:571-576 DOI 10.1007/s00128-013-1100-x.

Chen L, Long X-H, Zhang Z-H, Zheng X-T, Rengel Z, Liu Z-P. 2011. Cadmium Accumulation and Translocation in Two Jerusalem Artichoke (Helianthus tuberosus L.) 
Cultivars. Pedosphere 21:573-580 DOI 10.1016/s1002-0160(11)60159-8.

Choppala G, Saifullah, Bolan N, Bibi S, Iqbal M, Rengel Z, Kunhikrishnan A, Ashwath N, Ok YS. 2014. Cellular Mechanisms in Higher Plants Governing Tolerance to Cadmium Toxicity. Critical Reviews in Plant Sciences 33:374-391 DOI 10.1080/07352689.2014.903747.

Cobbett CS. 2000. Phytochelatins and their roles in heavy metal detoxification. Plant Physiology 123:825-832 DOI http://dx.doi.org/10.1104/pp.123.3.825

Fang ZG, Hu ZY, Zhao HH, Yang L,Ding CL, Lou LQ, Cai QS. 2016. Screening for cadmium tolerance of 21 cultivars from Italian ryegrass (Lolium multiflorum Lam) during germination. Grassland Science (First published: 24 January 2017) Available at http://onlinelibrary.wiley.com/doi/10.1111/grs.12138/full

Fernandez R, Bertrand A, Reis R, Mourato MP, Martins LL, Gonzalez A. 2013. Growth and physiological responses to cadmium stress of two populations of Dittrichia viscosa (L.) Greuter. Journal of Hazardous Materials 244:555-562 DOI 10.1016/j.jhazmat.2012.10.044.

Fernandez R, Fernandez-Fuego D, Bertrand A, Gonzalez A. 2014. Strategies for Cd accumulation in Dittrichia viscosa (L.) Greuter: role of the cell wall, non-protein thiols and organic acids. Plant Physiol Biochem 78:63-70 DOI 10.1016/j.plaphy.2014.02.021.

Gallego SM, Pena LB, Barcia RA, Azpilicueta CE, Iannone MF, Rosales EP, Zawoznik MS, Groppa MD, Benavides MP. 2012. Unravelling cadmium toxicity and tolerance in plants: Insight into regulatory mechanisms. Environmental and Experimental Botany 83:33-46 DOI 10.1016/j.envexpbot.2012.04.006.

Gill SS, Khan NA, Tuteja N. 2011. Differential cadmium stress tolerance in five Indian mustard (Brassica juncea L.) cultivars. Plant Signalling and Behaviour 6:293-300 DOI 10.4161/psb.6.2.15049.

Goncalves JF, Antes FG, Maldaner J, Pereira LB, Tabaldi LA, Rauber R, Rossato LV, Bisognin DA, Dressler VL, Flores EM, Nicoloso FT. 2009. Cadmium and mineral 
nutrient accumulation in potato plantlets grown under cadmium stress in two different experimental culture conditions. Plant Physiogyl and Biochemistry 47:814-821 DOI 10.1016/j.plaphy.2009.04.002.

Greger M, Kabir AH, Landberg T, Maity PJ, Lindberg S. 2016. Silicate reduces cadmium uptake into cells of wheat. Environmental Pollution 211:90-97 DOI 10.1016/j.envpol.2015.12.027.

Hegedüs A, Erdei S, Horváth G. 2001. Comparative studies of $\mathrm{H}_{2} \mathrm{O}_{2}$ detoxifying enzymes in green and greening barley seedlings under cadmium stress. Plant Science 160:1085-1093 DOI 10.1016/S0168-9452 (01)00330-2.

Kisa D, Ozturk L, Tekin S. 2016. Gene expression analysis of metallothionein and mineral elements uptake in tomato (Solanum lycopersicum) exposed to cadmium. Journal of Plant Research 129:989-995 DOI 10.1007/s10265-016-0847-7.

Knudson LL, Tibbitts T W, Edwards GE 1977. Measurement of Ozone Injury by Determination of Leaf chlorophyll concentration. Plant Physiology 60:606-608 DOI 10. 1104/pp.60.4.606.

Lin L, Zhou W, Dai H, Cao F, Zhang G, Wu F. 2012. Selenium reduces cadmium uptake and mitigates cadmium toxicity in rice. Journal of Hazardous Materials 235-236:343-351 DOI 10.1016/j.jhazmat.2012.08.012.

Liu Z, He X, Chen W, Zhao M. 2013. Ecotoxicological responses of three ornamental herb species to cadmium. Environmental Toxicology and Chemistry 32:1746-1751 DOI 10.1002/etc.2237.

Lopes Júnior CA, Mazzafera P, Arruda MAZ. 2014. A comparative ionomic approach focusing on cadmium effects in sunflowers (Helianthus annuus L.). Environmental and Experimental Botany 107:180-186 DOI 10.1016/j.envexpbot.2014.06.002.

Martin SR, Llugany M, Barceló J, Poschenrieder C. 2012. Cadmium exclusion a key factor in differential Cd-resistance in Thlaspi arvense ecotypes. Biologia Plantarum 56:729-734 DOI 10.1007/s10535-012-0056-8 
426

427

428

429

430

431

432

433

434

435

436

437

438

439

440

441

442

443

444

445

446

447

448

449

450

451

452

McHugh JP, Spanier JG. 1994. Isolation of cadmium sensitive mutants in Chlamydomonas reinhardtii by transformation/insertional mutagenesis. FEMS microbiology letters 124:239-244 DOI https://doi.org/10.1111/j.1574-6968.1994.tb07290.x.

Metwally A, Safronova VI, Belimov AA, Dietz KJ. 2005. Genotypic variation of the response to cadmium toxicity in Pisum sativum L. Journal of Experimental Botany 56:167-178 DOI $10.1093 / \mathrm{j} x \mathrm{~b} / \mathrm{eri} 017$.

Mostofa MG, Seraj ZI, Fujita M. 2014. Exogenous sodium nitroprusside and glutathione alleviate copper toxicity by reducing copper uptake and oxidative damage in rice (Oryza sativa L.) seedlings. Protoplasma 251:1373-1386

DOI 10.1007/s00709-014-0639-7.

Mugica-Alvarez V, Cortés-Jiménez V, Vaca-Mier M, Domínguez-Soria V. 2015. Phytoremediation of Mine Tailings Using Lolium Multiflorum. International Journal of Environmental Science and Development 6:246-251 DOI 10.7763/ijesd.2015.v6.599.

Mwamba TM, Li L, Gill RA, Islam F, Nawaz A, Ali B, Farooq MA, Lwalaba JL, Zhou W. 2016. Differential subcellular distribution and chemical forms of cadmium and copper in Brassica napus. Ecotoxicology and Environmental Safety 134:239-249 DOI 10.1016/j.ecoenv.2016.08.021.

Nadgorska-Socha A, Kafel A, Kandziora-Ciupa M, Gospodarek J, Zawisza-Raszka A. 2013. Accumulation of heavy metals and antioxidant responses in Vicia faba plants grown on monometallic contaminated soil. Environmental science and pollution research international 20:1124-1134 DOI 10.1007/s11356-012-1191-7.

Nocito FF, Lancilli C, Dendena B, Lucchini G, Sacchi GA. 2011. Cadmium retention in rice roots is influenced by cadmium availability, chelation and translocation. Plant Cell Environment 34:994-1008 DOI 10.1111/j.1365-3040.2011.02299.x.

Ozdener Y, Aydin BK. 2009. The effect of zinc on the growth and physiological and biochemical parameters in seedlings of Eruca sativa (L.) (Rocket). Acta Physiologiae Plantarum 32:469-476 DOI 10.1007/s11738-009-0423-z. 
453

454

455

456

457

458

459

460

461

462

463

464

465

466

467

468

469

470

471

472

473

474

475

476

477

478

479

Pannacci E, Pettorossi D, Tei F. 2013. Phytotoxic effects of aqueous extracts of sunflower on seed germination and growth of Sinapis alba L., Triticum aestivum L. and Lolium multiflorum Lam. Allelopathy Journal 32:23 Available at http://search.proquest.com/docview/1458282973?accountid=43630

Pandey VC, Bajpai O, Singh N. 2016. Energy crops in sustainable phytoremediation. Renewable and Sustainable Energy Reviews 54:58-73 DOI 10.1016/j.rser.2015.09.078.

Paschke MW, Valdecantos A, Redente EF. 2005. Manganese toxicity thresholds for restoration grass species. Environmental Pollution 135:313-322

DOI 10.1016/j.envpol.2004.08.006.

Ramos I, Esteban E, Lucena JJ, Gárate An. 2002. Cadmium uptake and subcellular distribution in plants of Lactuca sp. Cd-Mn interaction. Plant Science 162:761-767 DOI 10.1016/S0168-9452(02)00017-1.

Sarwar N, Malhi SS, Zia MH, Naeem A, Bibi S, Farid G. 2010. Role of mineral nutrition in minimizing cadmium accumulation by plants. Journal of the Science of Food and Agriculture 90:925-937 DOI 10.1002/jsfa.3916

Sghayar S, Ferri A, Lancilli C, Lucchini G, Abruzzese A, Porrini M, Ghnaya T, Nocito FF, Abdelly C, Sacchi GA. 2014. Analysis of cadmium translocation, partitioning and tolerance in six barley (Hordeum vulgare L.) cultivars as a function of thiol metabolism. 3:311-320 Biology and Fertility of Soils DOI 10.1007/s00374-014-0977-9.

Shi G, Cai Q. 2009. Cadmium tolerance and accumulation in eight potential energy crops. Biotechnology Advance 27:555-561 DOI 10.1016/j.biotechadv.2009.04.006.

Shi G, Liu C, Cui M, Ma Y, Cai Q. 2012. Cadmium tolerance and bioaccumulation of 18 hemp accessions. Applied Biochemistry Biotechnology 168:163-173 DOI 10.1007/s12010-011-9382-0.

Sun J, Cui J, Luo C, Gao L, Chen Y, Shen Z. 2013. Contribution of cell walls, nonprotein 
480

481

482

483

484

485

486

487

488

489

490

491

492

493

494

495

496

497

498

499

500

501

502

503

504

505

506

thiols, and organic acids to cadmium resistance in two cabbage varieties. Archives of Environment Contamination and Toxicology 64:243-252

DOI 10.1007/s00244-012-9824-x.

Tian S, Lu L, Zhang J, Wang K, Brown P, He Z, Liang J, Yang X. 2011. Calcium protects roots of Sedum alfredii H. against cadmium-induced oxidative stress. Chemosphere 84:63-69 DOI 10.1016/j.chemosphere.2011.02.054.

Tiryakioglu M, Eker S, Ozkutlu F, Husted S, Cakmak I. 2006. Antioxidant defence system and cadmium uptake in barley genotypes differing in cadmium tolerance. Journal of Trace Elements in Medicine and Biology 20:181-189 DOI 10.1016/j.jtemb.2005.12.004.

Toth G, Hermann T, Da Silva MR, and Montanarella L. 2016. Heavy metals in agricultural soils of the European Union with implications for food safety. Environment International 88:299-309 DOI 10.1016/j.envint.2015.12.017.

Uraguchi S, Fujiwara T. 2012. Cadmium transport and tolerance in rice: perspectives for reducing grain cadmium accumulation. Rice (N Y) 5:5 DOI 10.1186/1939-8433-5-5.

Wahid A, Arshad M, Farooq M. 2010. Cadmium phytotoxicity: responses, mechanisms and mitigation strategies: a review. Organic Farming, Pest Control and Remediation of Soil Pollutants: Springer, 371-403.

Wang M, Zou J, Duan X, Jiang W, Liu D. 2007. Cadmium accumulation and its effects on metal uptake in maize (Zea mays L.). Bioresource Technology 98:82-88 DOI 10.1016/j.biortech.2005.11.028.

Wu Z, Zhao X, Sun X, Tan Q, Tang Y, Nie Z, Qu C, Chen Z, Hu C. 2015. Antioxidant enzyme systems and the ascorbate-glutathione cycle as contributing factors to cadmium accumulation and tolerance in two oilseed rape cultivars (Brassica napus L.) under moderate cadmium stress. Chemosphere 138:526-536

DOI 10.1016/j.chemosphere.2015.06.080.

Xie P-p, Deng J-w, Zhang H-m, Ma Y-h, Cao D-j, Ma R-x, Liu R-j, Liu C, Liang Y-g. 2015. 
Effects of cadmium on bioaccumulation and biochemical stress response in rice (Oryza sativa L.). Ecotoxicology and Environmental Safety 122:392-398 DOI.

Yamada T, Inoue M, Stewart AV, Cai H, Saha MC, Rao KM, Rognli OA, Ellison NW, Bushman BS, Amundsen K. 2013. Genetics, genomics and breeding of forage crops. CRC Press, Boca Rato. 53-54.

Yasuda M, Takenouchi Y, Nitta Y, Ishii Y, Ohta K. 2015. Italian ryegrass (Lolium multiflorum Lam) as a High-Potential Bio-Ethanol Resource. Bioenergy Research 8:1303-1309. DOI 10.1007/s12155-015-9582-5.

Ye S, Yang Y, Xin G, Wang Y, Ruan L, Ye G. 2015. Studies of the Italian ryegrass-rice rotation system in southern China: Arbuscular mycorrhizal symbiosis affects soil microorganisms and enzyme activities in the Lolium mutiflorum L. rhizosphere. Applied Soil Ecology 90:26-34 DOI 10.1016/j.apsoil.2015.01.017.

Zhang H, Guo Q, Yang J, Chen T, Zhu G, Peters M, Wei R, Tian L, Wang C, Tan D, Ma J, Wang G, Wan Y. 2014. Cadmium accumulation and tolerance of two castor cultivars in relation to antioxidant systems. Journal of Environment Science 26:2048-2055 DOI 10.1016/j.jes.2014.08.005.

Zhang H, Zhang X, Li T, Fu H. 2013. Variation of cadmium uptake, translocation among rice lines and detecting for potential cadmium-safe cultivars. Environmental Earth Sciences 71:277-286 DOI 10.1007/s12665-013-2431-y. 
Figure 1

Cadmium concentration, translocation factors (TFs) and cadmium accumulation in two cultivars of Italian ryegrass

Data are means $\pm \mathrm{SE}$. (standard error) of three replicates. $* P<0.05 . * * P<0.01$. ns, not significant. Different letters indicate significant differences at $P<0.05$ according to the Duncan's multiple range test.
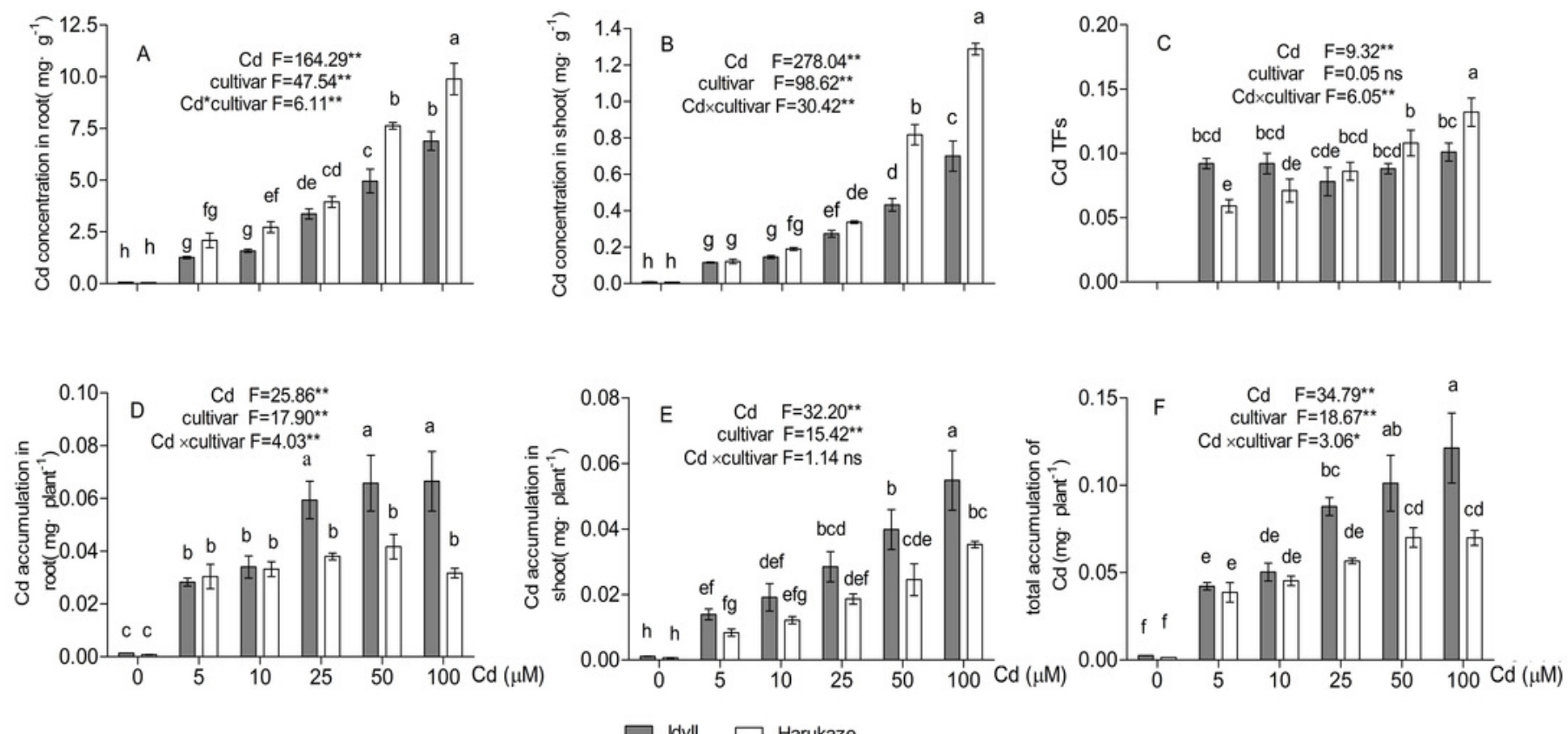
Figure 2

The distribution proportion of $\mathrm{Cd}(\mathrm{A})$ and $\mathrm{Cd}$ bioconcentration factors $(\mathrm{B})$ in roots under Cd stress

Data are means $\pm \mathrm{SE}$. of three replicates. ${ }^{*} P<0.05 .{ }^{*} P<<0.01$. ns, not significant. Different letters indicate significant differences at $P<0.05$ according to the Duncan's multiple range test.
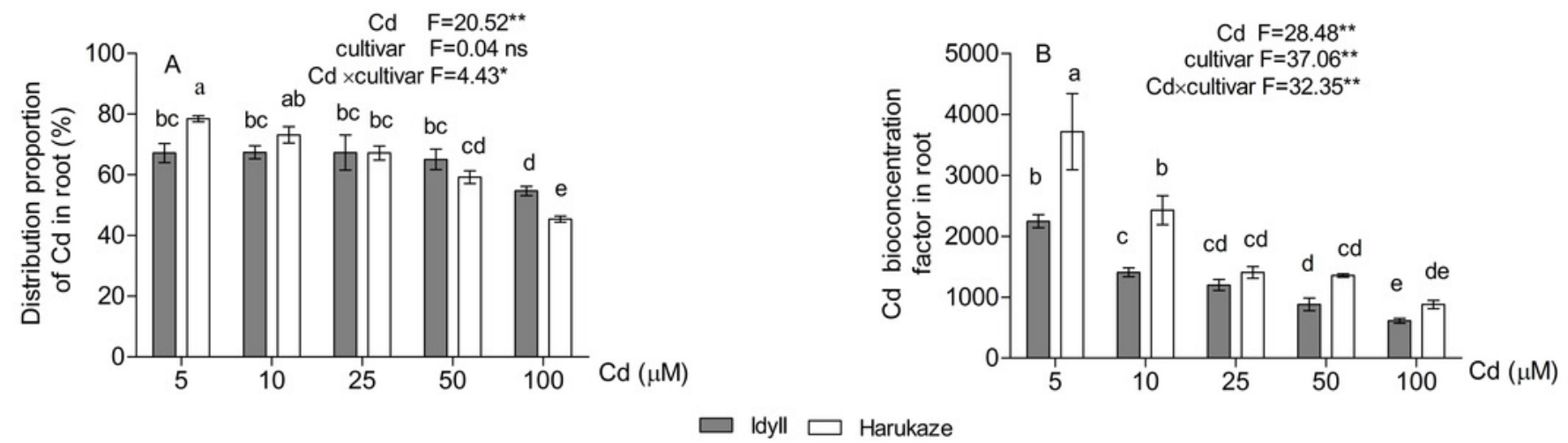
Figure 3

Nutrient element concentrations in the roots, shoot and TFs in the presence of Cd

Data are means \pm SE. of three replicates. $* P<0.05 . * * P<0.01$. ns, not significant. Different letters indicate significant differences at $P<0.05$ according to the Duncan's multiple range test.
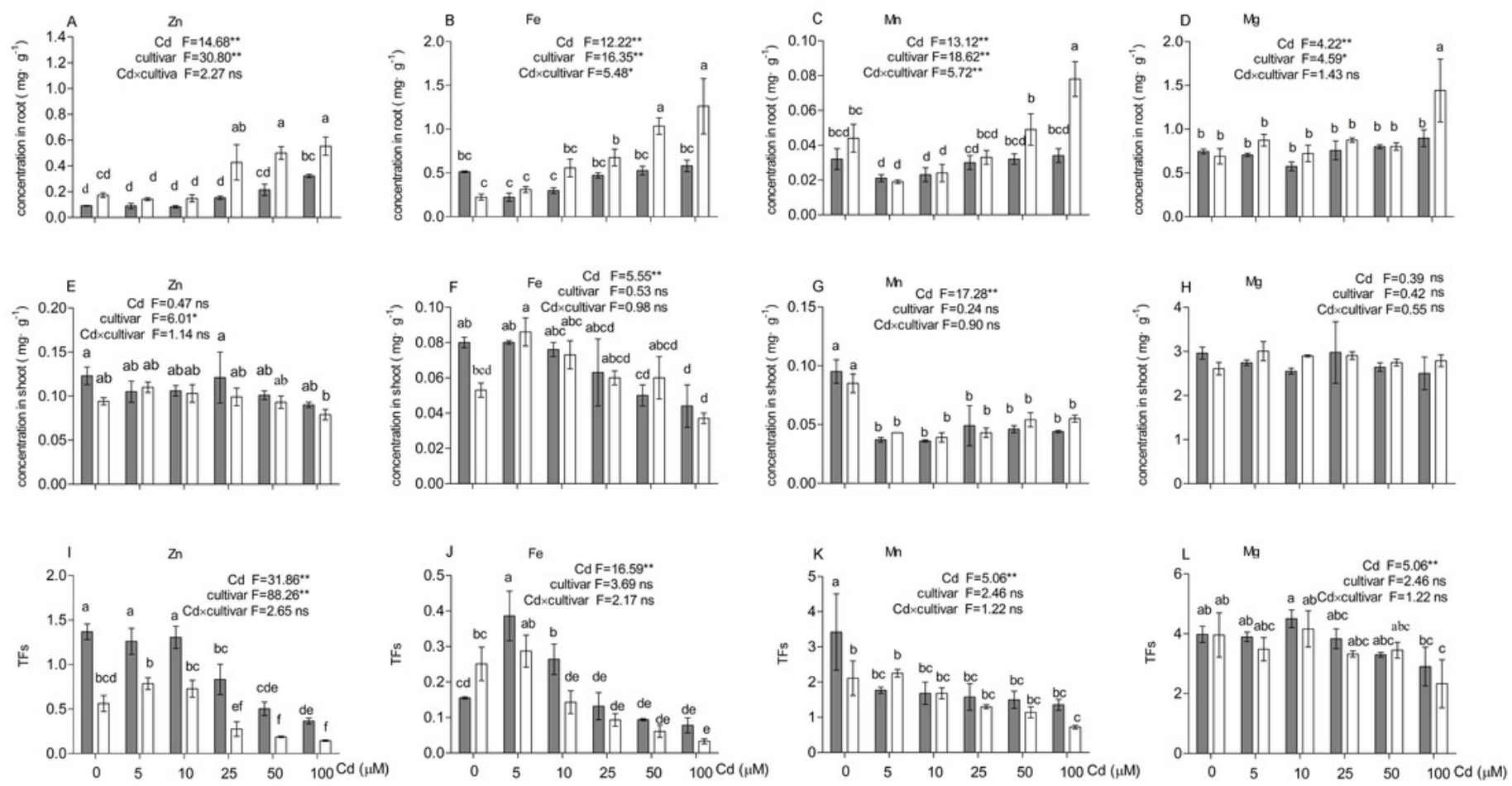
Figure 4

Effects of $\mathrm{Cd}$ on malondialdehyde (MDA) content in the roots and shoots of two Italian ryegrass cultivars

Data are means \pm SE. of three replicates. ${ }^{*} P<0.05$. ${ }^{*} P<<0.01$. ns, not significant. Different letters indicate significant differences at $P<0.05$ according to the Duncan's multiple range test.
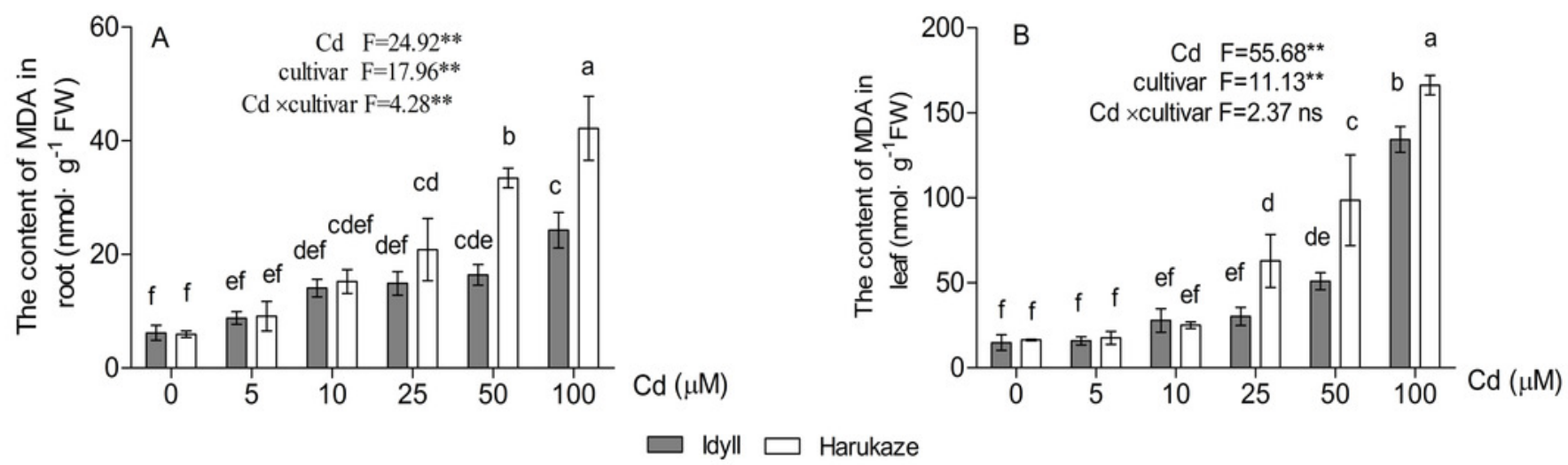
Figure 5

Effects of Cd on non-protein thiols (NPT) content in the roots and shoots of two Italian ryegrass cultivars

Data are means $\pm \mathrm{SE}$. of three replicates. $* P<0.05 . * * P<0.01$. ns, not significant. Different letters indicate significant differences at $P<0.05$ according to the Duncan's multiple range test.
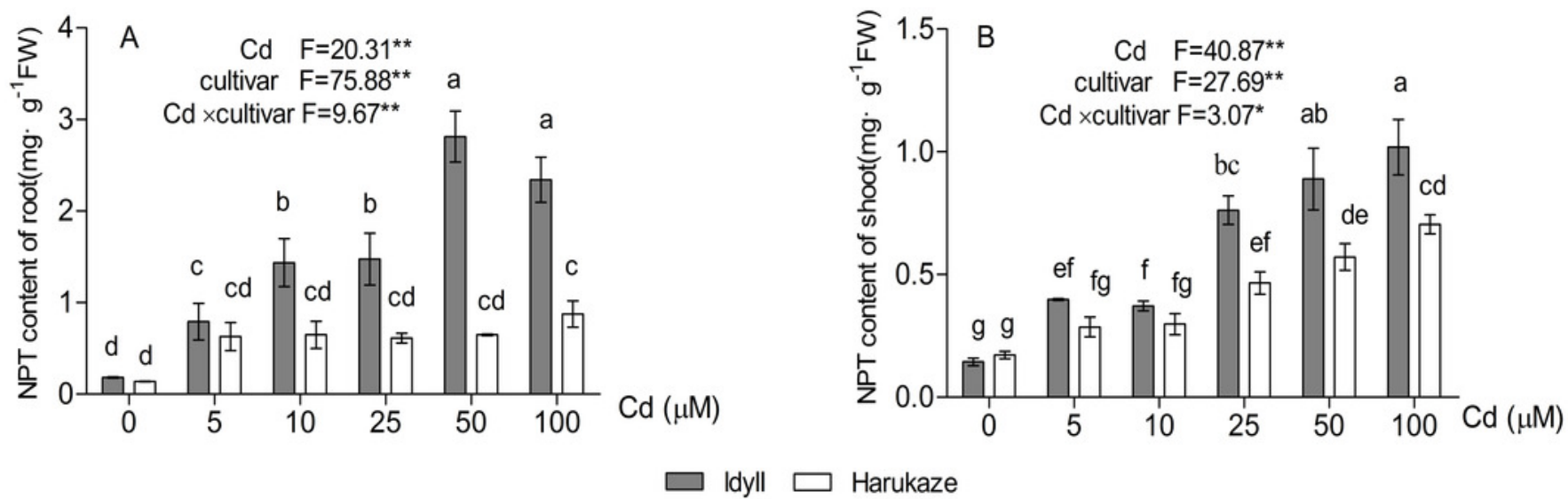


\section{Table $\mathbf{1}$ (on next page)}

Effects of $\mathrm{Cd}$ on plant biomass, $\mathrm{Cd}$ tolerance, and the root/shoot ratio in two cultivars of Italian ryegrass

DW, dry weight; TI, tolerance index; R, root; $S$, shoot. Values (means $\pm S . E ., n=3$ ) with different letters in the same columns are significantly different according to the Duncan's multiple range test . $* P<0.05, * * P<0.01, * * * P<0.001$, n.s., not significant. 
1

Table 1 Effects of Cd on biomass, Cd tolerance, and root/shoot in two cultivars of Italian ryegrass

\begin{tabular}{|c|c|c|c|c|c|c|}
\hline \multirow{2}{*}{ cultivar } & \multirow{2}{*}{ Cd supply $\mu \mathrm{M}$} & \multicolumn{2}{|c|}{ Plant biomass $\left(\mathrm{mg} \cdot\right.$ plant $\left.^{-1} \mathrm{DW}\right)$} & \multicolumn{2}{|c|}{ TIs } & \multirow[t]{2}{*}{ Root/Shoot ratio } \\
\hline & & $\mathrm{R}$ & $\mathrm{S}$ & $\mathrm{R}$ & S & \\
\hline \multirow{6}{*}{ IdyII } & 0 & $22.51 \pm 2.77 \mathrm{a}$ & $123.98 \pm 10.40 \mathrm{a}$ & & & $0.18 \pm 0.012 \mathrm{a}$ \\
\hline & 5 & $22.60 \pm 1.94 \mathrm{a}$ & $120.19 \pm 12.04 \mathrm{a}$ & $1.00 \pm 0.09 \mathrm{a}$ & $0.97 \pm 0.10 \mathrm{a}$ & $0.19 \pm 0.031 \mathrm{a}$ \\
\hline & 10 & $21.52 \pm 2.33 \mathrm{ab}$ & $113.92 \pm 14.28 \mathrm{a}$ & $0.96 \pm 0.10 \mathrm{ab}$ & $0.92 \pm 0.12 \mathrm{ab}$ & $0.19 \pm 0.005 \mathrm{a}$ \\
\hline & 25 & $17.54 \pm 1.09 \mathrm{bc}$ & $103.17 \pm 12.63 \mathrm{ab}$ & $0.78 \pm 0.05 \mathrm{bc}$ & $0.83 \pm 0.10 \mathrm{abc}$ & $0.18 \pm 0.036 \mathrm{a}$ \\
\hline & 50 & $13.30 \pm 1.57 \mathrm{cde}$ & $80.48 \pm 8.41$ bcd & $0.59 \pm 0.07 \mathrm{~d}$ & $0.65 \pm 0.07 \mathrm{c}$ & $0.16 \pm 0.003 \mathrm{ab}$ \\
\hline & 100 & $9.26 \pm 0.99$ ef & $78.08 \pm 7.86$ & $0.41 \pm 0.04 \mathrm{e}$ & $0.63 \pm 0.13 \mathrm{~cd}$ & $0.12 \pm 0.014 \mathrm{~b}$ \\
\hline \multirow{6}{*}{ Harukaze } & 0 & $15.29 \pm 0.99 \mathrm{~cd}$ & $84.00 \pm 5.05$ & & & $0.18 \pm 0.023 \mathrm{a}$ \\
\hline & 5 & $14.64 \pm 0.76 \mathrm{~cd}$ & $67.99 \pm 2.92$ & $0.96 \pm 0.05 \mathrm{ab}$ & $0.81 \pm 0.03 \mathrm{bc}$ & $0.22 \pm 0.006 \mathrm{a}$ \\
\hline & 10 & $12.26 \pm 0.90 \mathrm{de}$ & $63.36 \pm 3.64$ & $0.80 \pm 0.06 \mathrm{bc}$ & $0.75 \pm 0.04 \mathrm{bc}$ & $0.19 \pm 0.011 \mathrm{a}$ \\
\hline & 25 & $9.69 \pm 0.70$ ef & $55.06 \pm 3.74$ & $0.63 \pm 0.05 \mathrm{~cd}$ & $0.65 \pm 0.04 \mathrm{c}$ & $0.18 \pm 0.010 \mathrm{a}$ \\
\hline & 50 & $5.46 \pm 0.58 \quad \mathrm{fg}$ & $35.20 \pm 3.62$ & $0.36 \pm 0.04 \mathrm{ef}$ & $0.42 \pm 0.04 \mathrm{de}$ & $0.16 \pm 0.017 \mathrm{ab}$ \\
\hline & 100 & $3.22 \pm 0.13 \mathrm{~g}$ & $29.55 \pm 1.43$ & $0.21 \pm 0.01 \mathrm{f}$ & $0.35 \pm 0.02 \mathrm{e}$ & $0.11 \pm 0.007 \mathrm{~b}$ \\
\hline \multirow{3}{*}{$\begin{array}{l}\text { ANOVA } \\
\text { ( } F \text { values) }\end{array}$} & $\mathrm{Cd}$ & $153.72 * *$ & $11.04^{* *}$ & $38.32 * *$ & $11.87 * *$ & $5.97 *$ \\
\hline & cultivar & $25.79 * *$ & $92.04 * *$ & $15.15^{* *}$ & $18.93 * *$ & $0.017 \mathrm{n} . \mathrm{s}$ \\
\hline & $\mathrm{Cd} \times$ cultivar & $0.268 \mathrm{n} . \mathrm{s}$ & $0.13 \mathrm{n} . \mathrm{s}$ & $0.63 \mathrm{n} . \mathrm{s}$ & $0.24 \mathrm{n} . \mathrm{s}$ & $0.194 n . s$ \\
\hline
\end{tabular}
3 


\section{Table 2 (on next page)}

Fitted equations of $\mathrm{Cd}$ concentration and the inhibition rate of root or shoot biomass

$\mathrm{x}$ is $\mathrm{Cd}$ concentration, and $\mathrm{y}$ is inhabitation of root or shoot biomass. IC50 indicates an effective $\mathrm{Cd}$ concentration (when the root or shoot biomass decreased by $50 \%$ compared with the control), and IC90 indicates a lethal concentration (when the root or shoot biomass decreased by $90 \%$ compared with the control). ** indicates $P<0.01$. 


\begin{tabular}{|c|c|c|c|c|c|c|c|c|}
\hline cultivar & $\begin{array}{l}\text { Fit equations between } \mathrm{Cd} \\
\text { concentration and inhibition } \\
\text { rate of root biomass }\end{array}$ & $\begin{array}{l}\mathrm{IC}_{50} \\
(\mu \mathrm{M})\end{array}$ & $\begin{array}{c}\mathrm{IC}_{90} \\
(\mu \mathrm{M})\end{array}$ & $\mathrm{R}^{2}$ & $\begin{array}{c}\text { Fit equations between } \mathrm{Cd} \\
\text { concentration and inhibition rate } \\
\text { of shoot biomass }\end{array}$ & $\begin{array}{l}\mathrm{IC}_{50} \\
(\mu \mathrm{M})\end{array}$ & $\begin{array}{c}\mathrm{IC}_{90} \\
(\mu \mathrm{M})\end{array}$ & $\mathrm{R}^{2}$ \\
\hline IdyII & $y=-0.0049 x^{2}+1.1198 x-3.612$ & 68.27 & 192.03 & $0.991 * *$ & $y=-0.006 x^{2}+0.9837 x-1.2897$ & 124.73 & 174.14 & $0.989 * *$ \\
\hline Harukaze & $y=-0.01 x^{2}+1.7983 x-0.8778$ & 35.17 & 121.58 & $0.994 * *$ & $y=-0.009 x^{2}+1.4841 x+6.4125$ & 38.23 & 132.34 & $0.967 * *$ \\
\hline
\end{tabular}




\section{Table 3(on next page)}

Effects of $\mathrm{Cd}$ on the photosynthetic pigments in the leaves of two Italian ryegrass cultivars

Chl a, Chl b, and Car, indicate chlorophyll a, chlorophyll b, and carotenoids, respectively.

Values (means $\pm S E$., $n=3$ ) with different letters in the same columns are significantly

different according to the Duncan's multiple range test. $* P<0.05, * * P<0.01, * * * P<0.001$, n.s., not significant. 
1

\begin{tabular}{|c|c|c|c|c|c|c|}
\hline cultivar & $\begin{array}{c}\text { Cd supply } \\
\mu \mathrm{M}\end{array}$ & $\begin{array}{c}\text { chl a } \\
\mathrm{mg} \cdot \mathrm{g}^{-1} \mathrm{FW}\end{array}$ & $\begin{array}{c}\mathrm{chl} \mathrm{b} \\
\mathrm{mg} \cdot \mathrm{g}^{-1} \mathrm{FW}\end{array}$ & $\begin{array}{c}\mathrm{car} \\
\mathrm{mg} \cdot \mathrm{g}^{-1} \mathrm{FW}\end{array}$ & $\begin{array}{l}\operatorname{chl}(\mathrm{a}+\mathrm{b}) \\
\mathrm{mg} \cdot \mathrm{g}^{-1} \mathrm{FW}\end{array}$ & $\begin{array}{c}\mathrm{chl} \mathrm{a} / \mathrm{b} \\
\mathrm{mg} \cdot \mathrm{g}^{-1} \mathrm{FW}\end{array}$ \\
\hline \multirow{5}{*}{ IdyII } & 0 & $1.10 \pm 0.07 \mathrm{abc}$ & $0.34 \pm 0.01 \mathrm{ab}$ & $0.18 \pm 0.01 \mathrm{abc}$ & $1.44 \pm 0.05 \mathrm{ab}$ & $3.25 \pm 0.02 \mathrm{ab}$ \\
\hline & 5 & $1.03 \pm 0.09 \mathrm{bcd}$ & $0.32 \pm 0.02 \mathrm{abc}$ & $0.16 \pm 0.02 \mathrm{abcd}$ & $1.36 \pm 0.07 \mathrm{bc}$ & $3.21 \pm 0.05 \mathrm{abc}$ \\
\hline & 10 & $0.97 \pm 0.22 \mathrm{~cd}$ & $0.31 \pm 0.04 \mathrm{bc}$ & $0.16 \pm 0.02$ bcde & $1.28 \pm 0.16 \mathrm{bc}$ & $3.08 \pm 0.08$ abcd \\
\hline & 25 & $0.97 \pm 0.05 \mathrm{~cd}$ & $0.32 \pm 0.02 \mathrm{abc}$ & $0.14 \pm 0.03$ cde & $1.33 \pm 0.04 \mathrm{bc}$ & $3.05 \pm 0.22 \mathrm{abcd}$ \\
\hline & 50 & $0.86 \pm 0.01 \mathrm{~d}$ & $0.27 \pm 0.01 \mathrm{c}$ & $0.13 \pm 0.01 \mathrm{cde}$ & $1.13 \pm 0.02 \mathrm{c}$ & $3.13 \pm 0.12 \mathrm{abc}$ \\
\hline \multirow{7}{*}{ Harukaze } & 100 & $0.58 \pm 0.03 \mathrm{ef}$ & $0.20 \pm 0.01 \mathrm{~d}$ & $0.10 \pm 0.01 \mathrm{ef}$ & $0.79 \pm 0.01 \mathrm{de}$ & $2.86 \pm 0.20 \mathrm{bcd}$ \\
\hline & 0 & $1.20 \pm 0.12 \mathrm{ab}$ & $0.38 \pm 0.02 \mathrm{a}$ & $0.19 \pm 0.01 \mathrm{ab}$ & $1.60 \pm 0.10 \mathrm{a}$ & $3.17 \pm 0.08 \mathrm{abc}$ \\
\hline & 5 & $1.22 \pm 0.06 \mathrm{a}$ & $0.38 \pm 0.01 \mathrm{a}$ & $0.20 \pm 001 \quad \mathrm{a}$ & $1.60 \pm 0.05 \mathrm{a}$ & $3.18 \pm 0.04 \mathrm{abc}$ \\
\hline & 10 & $0.95 \pm 0.12 \mathrm{~cd}$ & $0.29 \pm 0.02 \mathrm{bc}$ & $0.14 \pm 0.01 \mathrm{cde}$ & $1.24 \pm 0.09 \mathrm{bc}$ & $3.34 \pm 0.04 \mathrm{a}$ \\
\hline & 25 & $0.69 \pm 0.06 \mathrm{e}$ & $0.21 \pm 0.01 \mathrm{~d}$ & $0.12 \pm 0.01 \mathrm{def}$ & $0.89 \pm 0.04 \mathrm{~d}$ & $3.30 \pm 0.03 \mathrm{a}$ \\
\hline & 50 & $0.48 \pm 0.11 \mathrm{f}$ & $0.17 \pm 0.02 \mathrm{~d}$ & $0.08 \pm 0.01 \mathrm{f}$ & $0.65 \pm 0.08 \mathrm{e}$ & $2.83 \pm 0.03 \mathrm{~cd}$ \\
\hline & 100 & $0.21 \pm 0.08 \mathrm{~g}$ & $0.07 \pm 0.02 \mathrm{e}$ & $0.03 \pm 0.01 \mathrm{~g}$ & $0.29 \pm 0.06 \mathrm{f}$ & $2.71 \pm 0.21 \mathrm{~d}$ \\
\hline \multirow{3}{*}{$\begin{array}{l}\text { ANOVA } \\
\text { ( } F \text { Values })\end{array}$} & $\mathrm{Cd}$ & $51.73 * * *$ & $42.84 * * *$ & $20.56^{* * *}$ & $51.17 * * *$ & $4.43 * *$ \\
\hline & cultivar & $15.04 *$ & $19.39 * * *$ & $4.92 *$ & $16.73 * * *$ & $0.01 \mathrm{~ns}$ \\
\hline & $\mathrm{Cd} \times$ cultivar & $9.584 * * *$ & $10.24 * * *$ & $5.39 * *$ & $10.18 * * *$ & $1.86 \mathrm{~ns}$ \\
\hline
\end{tabular}

2 
Table 4 (on next page)

Correlation coefficients $(n=30)$ among Cd Tls, uptake, translation, MDA, NPT in Italian ryegrass roots.

TIs, TFs, MDA, and NPT indicate tolerance indexes, translocation factors, malondialdehyde, and non-protein thiols, respectively. ${ }^{*} P<0.05 ;{ }^{* * P}<0.01$. 
1

Table 4 Correlation coefficients $(\mathrm{n}=30)$ among Cd tolerance, uptake, translation, MDA, NPT in Italian ryegrass root

\begin{tabular}{|c|c|c|c|c|c|c|}
\hline index & TIs & Cd concentration & TFs & Cd accumulation & MDA content & NPT content \\
\hline TIs & 1 & & & & & \\
\hline $\mathrm{Cd}$ concentration & $-0.922^{* *}$ & 1 & & & & \\
\hline TFs & $-0.612^{*}$ & $0.635^{*}$ & 1 & & & \\
\hline Cd accumulation & -0.185 & 0.293 & -0.003 & 1 & & \\
\hline MDA content & $-0.796^{* *}$ & $0.837^{* *}$ & $0.722^{* *}$ & 0.054 & 1 & \\
\hline NPT content & -0.143 & 0.147 & 0.04 & $0.738^{* *}$ & -0.072 & 1 \\
\hline
\end{tabular}

